\title{
Competency of Homestay as Society Empowerment in Millennial Age
}

\author{
Ni Desak Made Santi Diwyarthi ${ }^{1 *}$, Made Darmiati ${ }^{2}$, Ni Ketut Wiwiek Agustina ${ }^{3}$, Wayan Tagel Eddy ${ }^{4}$, \\ I Wayan Adi Pratama ${ }^{5}$ \\ $\left\{\underline{\left.\text { santidiwyarthi@yahoo.com }{ }^{1}\right\}}\right.$ \\ Program Studi Administrasi Perhootelan, Sekolah Tinggi Pariwisata Nusa Dua Bali, Indonesia ${ }^{123,}$ \\ Fakultas Sastra Universitas Udayana, Bali, Indonesia, ${ }^{4}$ Program Magister Pariwisata Universits \\ Udayaana, Bali, Indonesia ${ }^{5}$
}

\begin{abstract}
This study aims to identify Competencies of Homestay as Society Empowerment in Milenial Age. Increasing tourist for home sharing in some big city all around the world shows that homestay will grow bigger in the future. The data shows homestay has capability become society empowerment. The tourism minister plan to build 20,000 homestay in 2018, and 100,000 homestay in 2019. Tourism minister also plan to involve youth millennial tourist in the programs. This means homestay is important and need to prove the competencies in millennial age. This research are literature study research about competency of homestay as society empowerment in millenial age. The data collection techniques used are interviews, observation, documentation, and cheeck list. The theories used are homestay as community based tourism and sustainable tourism in Bali by I Wayan Adi Pratama. The results are Homestay haas comppetencies as social empowerment, Homestay management needs implementation on digital marketing in millennial age, Homestay management as leader promoting Balinese phylosophies.
\end{abstract}

Keywords: Homestay; Society Empowerment; Millennial Age

\section{Introduction}

Minister of Tourism on November 2018 said that The Ministery collaborate Millennials to promote tourism villages and homestay. The government policy to build 20,000 homestay all around Indonesia in 2018, and raise to 100,000 in 2019. The policy is because by develop homestay, community will develop their village. By having responsibility to build their own village, they will do the best.

Increasing tourist for home sharing, $10 \%$ during 2016, become $15 \%$ in 2020 in some big city all around the world, in South East Countries, $2 \%$ during 2016, become $5 \%$ in 2020. The data shows homestay has capability become society empowerment. Travel. Kompas.com on November 22th 2017, said that trends for 2018, tourists prefer to choose homestay better than hotel. The millenial young tourist is the most tourist stayed at homestay. The Tourism Ministerial collaborate young millennial to promote homestay.

Pratama said that homestay having good prospect for the future, involve community to plan and implement the programs at their village, with the culture, Tri Hita Karana [1]. This means that homestay will grow and having good impact for the society, and need responsibility between stakeholder to prove the existence of homestay in the future. 
Chief Communication and Co Founder Tiket.com, Gaery Undarsa said the trend of non-hotel acomodation will be booming in 2018 surround Indonesia millennial tourists. This is because of price competition.

\section{Method}

This research is a theoretical study of society empowerment in millennial age. This research can be categorized into qualitative research with qualitative data. The qualitative data were obtained from data sources that can be divided into two, namely primary data sources and secondary data sources [2]. The data collection was done by observation, interview, and literature study.

\section{Result and Discussion}

\subsection{Millennials}

Millennials are the largest generation ever to drive and walk the road of this planet, and they are already old enough to speak for themselves. Milenials are generally described as the generation born between early 1980s and 2002, but rarely do people give an extra thought to dfferent countries' cultural, political and historical contexts that affect generational differences in different places. It means, in the global context, no all mmillennials actually belong to the same generation.

Millennials differ, even, from country to country within the same regions. "A global study of 16,000 millennials in 43 countries, conducted in 2014 and co-sponsored by INSEAD Emerging Markets Institute, The Head Foundation and Universum - Reveals that Millennils not only differ from region to region, bu even from country to country within those rregions of the world".

According to the 2017 Deloitte Millenial Survey, Millennials are becoming increasingly loyal to their current employer as thy get older (even more so than the Generation $\mathrm{X}): 38 \%$ of millennials plan to leave within 2 years, compared to $44 \%$ in $2016 ; 31 \%$ plan to stay beyond 5 years, compared to $27 \%$ in $2016 ; 7 \%$ plan to leave soon, compared to $17 \%$ in 2016.

More than $40 \%$ of Millennials in the Asian Pacific Region expect astandard of living higher than tht of their parents. So do only $9 \%$ of Japanese Millennials. South African Millennials are less likely to see themselves as enterpreneurial compared to Nigerian Millennials. Becoming a leader is more important to Russian Millennials, while millennials from Poland, Slovakia and Czech Republic prioritize growing and learning new things.

\subsection{Homestay}

The number of tourist visit to Buleleng continuous to increase, especially in tourist attractions such as Gitgit Waterfalls, Hot Spring Yeh Panes, Buleleng Harbor, Lovina Beach. Almost 125.000 tourists visit Buleleng Regency in 2016. More than $5 \%$ over the previous year [3].

Tourist visit certainly needs adequate accommodation, attractions, amenities, transportation, such as hotel, restaurants, destinations. There are more than 300 homestay at 
Buleleng Regency, having cost at 250.000 to 1.000 .000 rupiah. Tourists stay and having local experience daily with local people.

Pratama said that homestay having good prospect for the future, involve community to plan and implement the programs at their village, with the culture, Tri Hita Karana. The result of his research explain that homestay as a good implementation of a Community Based Tourism and Sustainable Tourism, works as: (1) a Conservator for environment \& socioculture value from local wisdom, (2) Catalyzer for improving socio-economic standard of living, (3) a Facilitator to provide tourist accomodation in tourim destination, (4) as a Promotor to indirectly promoting destination by website and online travel agent [1].

\subsection{Society Empowerment}

Society empowerment is a process provides life skills, sports, leadership and management traaining, to engage people, especially youth, to develop community abilities and competencies public participation to build their village [4].

Not only obey the rule made by The Government, management of Homestay obey the regulation of customary law (hukum adat). Windia and Sudantra explain Adat Laws grow in Indonesia Society which is in the form of legal norms that arise and grow inside and are caused by the association of human life, both in its written and unwritten forms [4].

Hiroyuki, Juliartawan, and Sudarsana said that the tradition has a series of ceremonies and implementation plans. It means that although the tradition is shown to the guest living in a homestay, the tradition itself does not lose the character values [5].

Jero Mangku, the owner of homestay at Kalibukbuk said, "Having homestay is a new challenges for our family. My wife is a good cook at one restaurant. I asked her for stay at home and we start to manage our own homestay".

112 guests stay at homestay in Kalibukbuk, Buleleng Regency prefer to choose homestay better than a hotel when stay in Bali, because of the quality of service, wanna feel the atmosphere, interract with the community, seeing the culture, the tradition, and the food in the village" [6].

Increasing tourist for home sharing, as said by Tourism Minister, $10 \%$ in 2016 to $15 \%$ in 2020, show us the increasingly of homestay competencies in young millennial tourists.

Mrs. Ida, an official government said, homestay has big impact in sustainable development. Homestay give a chance for community to be a part in sustainable development, providing home, processing the surrounding environment, providing transportation facillities, maintaining security, designing activities, even, designing various interesting accessories.

Jero Mangku said, "I manage homestay with my family. I still do my job as driver, my wife still do his favourite job as cook for the guest at our homestay, and we work together with all of our family without leaving our tradition and our daily activities".

This means by manage homestay, the family still could protect tradition, doing ceremonies, develop their skill, working for life, build their villages, and stay with family. In according to Eko Prasodjo said, "Society empowerment is a process provides life skills, sports, leadership and management training, to engage people, especially youth, to develop community abilities and competencies public participation to build their village" [7].

Not only obey the rule made by The Government, management of Homestay obey the regulation of customary law (hukum adat). Windia and Sudantra explain Adat Laws grow in Indonesia Society which is in the form of legal norms that arise and grow inside and are caused by the association of human life, both in its written and unwritten forms [4].

Paramitha finding results shows that tradition follows by a series of ceremonies, with implementation plans initiated by initiator. The internalization of character values through 3 
stages, namely the value transformtion stage, transaction value stage, and transinternalisation value. It means when a tourist dicide to stay at homestay, they want the value will reach the same level as they want [8].

The existence of homestay with all activities, means they could protect tradition together, asking the tourist to involve ith their family activities, and community village activities. As Hiroyuki, Juliawan, and Sudarsana said that the tradition has a series of ceremonies and implementation plans. It means that although the tradition is shown to the guest living in a homestay, the tradition itself does not lose the character values [5]. As said by Pratama "Homestay having good prospect for the future, involve community to plan and implement the programs at their village, with the culture, Tri Hita Karana" [1].

The existence of homestay need an acceleracy and accuracy information to the tourist all over the world, so digital marketing is a must. As said by Pratama "Homestay is a facilitator to provide tourist accomodation in tourim destination and as a promotor to indirectly promoting destination by website and online travel agent [1].

\section{Conclusion}

a. Homestay has competencies as social empowerment. The existency of homestay involve community to plan and implement the program for their village, protect and develop the culture, especially tradition, learn and practice skill for life.

b. Homestay management need implementation on digital marketing in millenial age. Millennial age needs acceleration, accuracy, and spreads worldwide information, multi sector, cross culture, borderless world. And, the only way is go digital.

c. Homestay management as leader promoting Bali philosophy. As society empowerment, Homestay managemment provide community to implementate Tri Hita Karana, Desa, Kala, Patra, and having responsibility it happens properly in their village.

\section{References}

[1] I. W. A. Pratama, Homestay Role to Sustainable Tourism Development in Ubud. Denpasar: Sekolah Tinggi Pariwisata Nusa Dua, 2017.

[2] I. K. Sudarsana, I. G. Ngurah Agung Wijaya Mahardika, I. M. Arsa Wiguna, N. K. Juliantari, and I. N. Warta, "The Existence Of Puja Mandala In Manifesting Tolerance Education," vol. 203, no. Iclick 2018, pp. 340-342, 2019.

[3] Ni Desak Made Santi Diwyarthi, Tourist Satifaction toward Homestay Management of Lumajang Regency. Denpasar: Sekolah Tinggi Pariwisata Nusa Dua Bali, 2018.

[4] A. Sandria, "Pancasila Values In Tradition On The Bali Hindu Community Reviewed From Bali Adat Law And Hindu's Law," Vidyottama Sanatana Int. J. Hindu Sci. Relig. Stud., vol. 2, no. 2, pp. 226-231, 2018.

[5] A. Hiroyuki, J. Juliawan, and I. K. Sudarsana, "Internalization Values Of Character Education Towards The Teruna-Daha In The Medi-Median Tradition," Vidyottama Sanatana Int. J. Hindu Sci. Relig. Stud., vol. 2, no. 2, p. 232, Nov. 2018.

[6] N. D. M. S. Diwyarthi, Quality of Service towards Guest Satisfction on Homestay Management in Kalibukbuk, Buleleng Regency. Denpasar: Sekolah Tinggi Pariwisata Nusa Dua Bali, 2018.

[7] E. Prasojo and T. Kurniawan, "Reformasi Birokrasi dan Good Governance : Kasus Best Practices dari Sejumlah Daerah di Indonesia," Symp. A Q. J. Mod. Foreign Lit., 2008.

[8] N. M. A. S. P. Paramitha, "Theological Symbolisation Of Watugunung Myth And Sangkuriang 
Legend ( Comparative Literature Study )," Vidyottama Sanatana Int. J. Hindu Sci. Relig. Stud., vol. 2, no. 2, pp. 211-217, 2018. 